\title{
Persepsi Kondisi Kerja dan Kinerja Karyawan Generasi Y
}

\author{
Perception of Working Condition and Performance of the Generation Y Employees
}

Tri Yulyanti Fathonah ${ }^{1 *}$, Aida Vitayala Hubeis², dan Nurmala K Panjaitan ${ }^{2}$

${ }^{1}$ Program Pascasarjana Manajemen dan Bisnis, Institut Pertanian Bogor

Jl. Raya Pajajaran Bogor, 16151; E-mail: t.yulyanti@gmail.com; Hp : 08568112462

${ }^{2}$ Departemen Sains Komunikasi dan Pengembangan Masyarakat,

Fakultas Ekologi Manusia, Institut Pertanian Bogor

Jl. Kamper Wing 1 Lantai 2 Kampus IPB Darmaga Bogor, 16680

\begin{abstract}
ABSTRAK
Generasi Y merupakan generasi terbaru dari pekerja yang memasuki angkatan kerja saat ini. Semakin banyak generasi $Y$ yang memasuki angkatan kerja saat ini memberikan tantangan tersendiri bagi perusahaan. Penelitian ini bertujuan menganalisis persepsi karyawan generasi $Y$ pada kondisi kerja di PT XYZ dan menganalisis kinerja karyawan generasi Y di PT XYZ. Penelitian dilakukan di PT XYZ dengan melibatkan karyawan generasi $\mathrm{Y}$ sebagai responden. Teknik pengumpulan data dilakukan melalui penyebaran kuesioner, wawancara dan studi dokumentasi. Responden dipilih dengan metode pengambilan contoh acak (simple random sampling). Contoh penelitian berjumlah 66 orang, terdiri dari 46 orang karyawan laki-laki dan 20 orang karyawan perempuan. Tahap awal analisis data dilakukan dengan statistik deskriptif yang dilanjutkan dengan uji beda uji Mann Whitney dari program Statistical Package for the Social Science (SPSS) versi 16. Hasil penelitian menunjukkan karyawan generasi Y laki-laki dan perempuan memiliki persepsi positif mengenai kondisi kerja yang ada di PT XYZ. Nilai rataan skor kinerja karyawan generasi $Y$ berdasarkan jenis kelamin mengarah positif. Nilai rataan skor kinerja yang tinggi menyatakan bahwa karyawan generasi Y laki-laki dan perempuan sudah memberikan kinerja terbaiknya bagi PT XYZ. Strategi yang dapat dilakukan dalam mempertahankan dan meningkatkan kinerja karyawan, antara lain, melakukan pengkajian ulang atas kebijakan penentuan gaji dan tunjangan dihitung berdasarkan kinerja standar dan aktual berdasarkan hasil kerja karyawan sesuai dengan tugas dan tanggung jawabnya, memberikan apresiasi kepada karyawan yang telah mencapai hasil kinerja yang maksimal dengan memberikan penghargaan, serta mengagendakan kegiatan fun gathering dan team building dalam rangka meningkatkan kerja tim antar rekan kerja dan memberikan penyegaran kepada karyawan di tengah-tengah rutinitasnya bekerja.
\end{abstract}

Kata kunci: generasi Y, karyawan, kinerja, kondisi kerja

\begin{abstract}
Generation $\mathrm{Y}$ is the latest generation of workers entering the workforce nowadays. The increasing number of generation $\mathrm{Y}$ entering the workforce nowadays has provided challenges for PT XYZ. The purposes of this research are to analyze the perception of generation $\mathrm{Y}$ employees toward the working conditions at PT XYZ and to analyze the performance of generation $\mathrm{Y}$ employees at PT XYZ. The research was conducted at PT XYZ involving generation $Y$ employees as respondents. Data was collected using questionnaires, interviews, and documentation. Respondents were selected by simple random sampling. The research sample were 66 employees, consisted of 46 men and 20 women employees. The initial stage of data analysis was conducted using descriptive statistics, linear regression analysis and Mann Whitney test using SPSS version 16. The research found that employees generation $Y$ both men and women have positive perception of working conditions at XYZ. The average value scores of generation $\mathrm{Y}$ employees' performance based on gender leads to positive. The performance indicator that
\end{abstract}

\footnotetext{
*) Korespondensi:

Jl. Raya Pajajaran Bogor, 16151; E-mail: t.yulyanti@gmail.com; Hp : 08568112462
} 
has the highest value on the employees of Generation Y (both men and women and has positive perception is cooperative attitude. Strategies that suggested to maintain and improve employee performance they are review of policy determination of salary and benefits are calculated based on performance standards and real-time based on the results of the employee according to his duties and responsibilities, giving reward as appreciation to employees who have achieved maximum performance results, as well as scheduling fun activities gathering and team building in order to improve teamwork between colleagues and give refreshment to the employees in the middle of their routine work.

Key words: employees, generation Y, performance, working condition

\section{PENDAHULUAN}

PT XYZ adalah salah satu Badan Usaha Milik Negara (BUMN) industri strategik yang memproduksi bahan peledak dan senjata. Tahun 2002 merupakan titik awal bagi PT XYZ melakukan transformasi penyesuaian terhadap perubahan eksternal dan internal. Perubahan eksternal yang terjadi adalah adanya perubahan ketentuan perundangan di bidang bahan peledak dari yang semula monopoli menjadi persaingan pasar, dimana awalnya PT XYZ memiliki hak monopoli penjualan bahan peledak di Indonesia. Perubahan kondisi internal berupa ketidakpuasan karyawan atas kinerja perusahaan yang menurun sebagai dampak dibukanya monopoli produksi dan perdagangan bahan peledak. Sebelum transformasi, sumber daya manusia (SDM) PT XYZ sebanyak $60 \%$ berasal dari lulusan Sekolah Lanjutan Tingkat Atas (SLTA) dan Sekolah Menengah Pertama (SMP), setelah transformasi, sebanyak $60 \%$ berasal dari lulusan SLTA dan hanya satu persen berasal dari lulusan SMP (Rahayu, 2015). Program management trainee dipilih, karena program tersebut tepat dalam menyelesaikan permasalahan yang dihadapi PT XYZ mengenai regenerasi karyawan dan memperoleh calon karyawan berkompeten di level manajerial dengan waktu tidak relatif lama. Melalui program management trainee, karyawan baru dituntut untuk mengetahui proses bisnis secara cepat dan tepat. Oleh karena itu, PT XYZ melaksanakan program management trainee sebagai transformasi dalam merekrut karyawannya.

Persyaratan yang ditetapkan dalam program management trainee, antara lain perempuan atau laki-laki, maksimal berusia 30 tahun, pendidikan terakhir D3/S1/S2, memiliki IPK minimal 2,75 untuk lulusan science dan IPK minimal 3,00 untuk lulusan sosial, mampu berkomunikasi dalam bahasa Inggris, mampu mengoperasikan komputer (MS Office), memiliki jiwa kepemimpinan, dinamis, motivasi yang tinggi dan mampu berkomunikasi dengan baik serta persyaratan lainnya. Karyawan yang telah lulus seleksi akan menjalani masa orientation job training (OJT) selama sembilan bulan dengan pemindahan lokasi kerja sebanyak tiga kali per tiga bulan. OJT bertujuan agar karyawan baru dapat mengenal dan memahami proses bisnis yang ada di PT XYZ dan jika sewaktu-waktu diperlukan rotasi, maka setiap karyawan sudah memiliki dasar pemahaman proses bisnis di posisi yang baru. Setelah masa OJT, karyawan baru dan yang belum pernah mengikuti pelatihan dasar kepemimpinan (latsarpim) diwajibkan mengikutinya. Pelatihan tersebut bertujuan membentuk sikap dan mental karyawan agar memiliki nilai juang, membangun kerjasama dan kekompakan setiap personil dalam melaksanakan tugas, jiwa korsa, disiplin, kepemimpinan, nasionalisme dan mampu menjalin komunikasi dengan baik antara atasan maupun bawahan sesuai koridor dengan benar.

Target PT XYZ ke depannya adalah komersialisasi produk PT XYZ dengan menyasar tambang besar yang masih menggunakan produk impor, mampu bersaing dan menjadi pemain utama di pasar ASEAN. Target tersebut terasa berat untuk dicapai dengan adanya kemunculan generasi Y. Berdasarkan persyaratan program management trainee, karyawan yang lulus seleksi termasuk ke dalam kategori generasi Y. Menurut Meier dan Crocker (2010), generasi Y adalah generasi yang lahir antara tahun 1980-2000. Generasi Y merupakan generasi terbaru dari pekerja yang memasuki angkatan kerja saat ini. Semakin banyaknya generasi $\mathrm{Y}$ yang memasuki angkatan kerja saat ini memberikan tantangan tersendiri bagi organisasi. Hal tersebut dipengaruhi oleh karakternya yang berbeda dengan generasi lain dalam hal nilai dan sikap yang berhubungan dengan pekerjaan. Salah satu cara yang dapat dilakukan agar PT XYZ dapat mencapai target-targetnya adalah mempersiapkan dan meningkatkan mutu SDM agar memiliki 
kemampuan lebih tinggi dalam menciptakan produk-produk inovasi baru dan lebih menginovasi produk-produk yang sudah ada melalui pengembangan teknologi untuk memperkuat daya saing di pasar lokal dan internasional.

Upaya yang dilakukan oleh PT XYZ untuk meningkatkan mutu sumber daya manusia adalah memberikan kesempatan bagi seluruh karyawan untuk mengikuti pelatihan berjenjang termasuk pelatihan ke luar negeri bagi karyawan berprestasi dan mampu berkiprah di ajang internasional. Memberikan peluang promosi dan jenjang karir yang menjanjikan bagi seluruh karyawan. Memberikan apresiasi berupa wisata keliling kota selama tiga hari bersama keluarga. Wisata keliling kota bertujuan untuk meningkatkan prestasi dan membangun kepercayaan keluarga karyawan, sehingga keluarganya mendorong karyawan untuk meningkatkan kinerjanya. Oleh karena itu, PT XYZ menjadikan pelatihan sebagai sumber motivasi dan investasi jangka panjang khususnya inovasi produk dan proses teknologi bahan peledak.

Mangkuprawira dan Hubeis (2007), menyatakan bahwa Herzberg dengan teori dua faktor motivasi, yaitu para karyawan di dalam melaksanakan pekerjaannya dipengaruhi oleh faktor, seperti ekstrinsik dan intrinsik sebagaimana terlihat pada Tabel 1. Faktor kondisi ekstrinsik kalau tidak ada akan menyebabkan karyawan tidak puas. Utamanya faktor tersebut untuk mempertahankan kebutuhan karyawan tingkat paling rendah, seperti balas jasa gaji dan upah, kondisi kerja, kebijakan dan administrasi perusahaan, kepastian pekerjaan, serta hubungan sosial. Faktor motivasi menyangkut kebutuhan psikologis yang berhubungan dengan penghargaan terhadap pribadi karyawan yang terkait dengan pekerjaan. Contohnya, pengakuan terhadap prestasi, pemberian tanggungjawab, kemajuan, potensi diri dan penempatan posisi pekerjaan karyawan yang sesuai.

Herzberg dalam Intani (2013) mengemukakan teori dua faktor atau sering disebut sebagai "Herzberg Two Factor Motivation Theory". Dua jenis faktor yang mendorong seseorang untuk berusaha mencapai kepuasan dan menjauhkan diri dari ketidakpuasan. Dua faktor itu disebut faktor hygiene (faktor ekstrinsik) dan faktor motivator (faktor intrinsik). Menurut teori, kedua faktor merupakan kebutuhan, yaitu: faktor ekstrinsik atau hygiene. Serangkaian kondisi ekstrinsik menyebabkan keadaan pekerjaan yang menye- babkan rasa tidak puas, apabila kondisi tersebut tidak ada. Kondisi ini yang membuat orang tidak puas atau disebut hygiene factor. Kebutuhan ini berlangsung terus menerus, karena pegawai tidak akan mendapat kepuasan. Faktor intrinsik atau faktor motivasi menyangkut kebutuhan psikologis yang berkaitan dengan pekerjaan. Kebutuhan ini meliputi serangkaian kondisi intrinsik, kepuasan pekerjaan yang akan mendorong motivasi kuat dan dapat menghasil-kan prestasi kerja. Keberhasilan pencapaian tujuan tidak terlepas dari pengelolaan karyawan yang disertai motivasi baik dari karyawan itu sendiri maupun dari pimpinannya. Kendala yang dihadapi oleh seorang pemimpin adalah adanya perbedaan motivasi pada masing-masing karyawan. Oleh karena itu, seorang pemimpin sebaiknya memiliki keterampilan memahami dan menciptakan suasana yang mampu memotivasi karyawannya untuk mencapai tujuan perusahaan.

Tabel 1. Teori dua faktor Herzberg

\begin{tabular}{|c|c|c|}
\hline No & Faktor ekstrinsik & Faktor intrinsik \\
\hline 1. & $\begin{array}{l}\text { Kebijakan perusahaan } \\
\text { Peraturan dan kebijak- } \\
\text { an yang mengatur } \\
\text { bagaimana organisasi } \\
\text { menjalankan bisnisnya. }\end{array}$ & $\begin{array}{l}\text { Prestasi } \\
\text { Melakukan pekerjaan } \\
\text { dengan baik: rapat dan } \\
\text { menetapkan target. }\end{array}$ \\
\hline 2. & $\begin{array}{l}\text { Supervisi } \\
\text { Mengelola karyawan } \\
\text { dalam menyelesaikan } \\
\text { tugasnya dari hari ke } \\
\text { hari. }\end{array}$ & $\begin{array}{l}\text { Pengakuan } \\
\text { Manajer dan para kolega } \\
\text { mengakui prestasi individu. }\end{array}$ \\
\hline 3. & $\begin{array}{l}\text { Hubungan } \\
\text { interpersonal } \\
\text { Hubungan dengan } \\
\text { kolega di tempat kerja. }\end{array}$ & $\begin{array}{l}\text { Pekerjaan itu sendiri } \\
\text { Karyawan percaya bahwa } \\
\text { menyelesaikan tugas adalah } \\
\text { penting. }\end{array}$ \\
\hline 4. & $\begin{array}{l}\text { Kondisi kerja } \\
\text { Jam kerja, tatanan } \\
\text { tempat kerja, fasilitas, } \\
\text { dan perlengkapan } \\
\text { teknis. }\end{array}$ & $\begin{array}{l}\text { Tanggung jawab } \\
\text { Menumbuhkan rasa } \\
\text { memiliki terhadap pekerjaan } \\
\text { dengan memberikan } \\
\text { kebebasan kepada karyawan } \\
\text { dalam menjalankan } \\
\text { tugasnya. }\end{array}$ \\
\hline 5. & $\begin{array}{l}\text { Gaji dan tunjangan } \\
\text { Kompensasi yang adil } \\
\text { dalam gaji dasar, } \\
\text { ditambah tunjangan, } \\
\text { bonus, tunjangan hari } \\
\text { raya, dan fasilitas mobil } \\
\text { dari perusahaan. }\end{array}$ & $\begin{array}{l}\text { Kemajuan } \\
\text { Karyawan membuat } \\
\text { kemajuan tidak hanya } \\
\text { melalui promosi, tetapi } \\
\text { melalui kesempatan untuk } \\
\text { berkembang. }\end{array}$ \\
\hline
\end{tabular}

Beberapa program lain yang dilakukan oleh PT XYZ dalam memberikan kenyamanan dalam bekerja, meliputi annual medical check up dan "tuesday move on". Program "tuesday move on" 
dilakukan sebulan sekali pada hari selasa minggu ketiga. Program ini dilakukan untuk menggali talenta karyawan dalam berbagai bidang seni dan menghibur karyawan di sela-sela kesibukannya bekerja. Berbagai upaya yang telah dilakukan tersebut diharapkan dapat memberikan keterikatan kepada karyawan untuk memberikan loyalitas, menyelesaikan permasalahan regenerasi karyawan dan dapat menghasilkan kinerja perusahaan yang baik. Kinerja karyawan salah satunya dipengaruhi oleh motivasi. Kinerja adalah hasil dari proses pekerjaan tertentu secara terencana pada waktu dan tempat dari karyawan, serta organisasi bersangkutan (Mangkuprawira dan Hubeis, 2007). Mathis dan Jackson (2002) mengatakan bahwa kinerja dapat diartikan sebagai sesuatu hal baik yang dilakukan, maupun yang tidak dilakukan. Kinerja karyawan sangat berpengaruh terhadap produktivitas perusahaan. Pengaruh ini dapat dilihat dari seberapa banyak kontribusi yang diberikan kepada perusahaan, yaitu:

\section{Kuantitas dari hasil}

Jumlah atau tingkat kuantitas dari hasil yang dihasilkan karyawan dalam waktu tertentu.

\section{Mutu dari hasil}

Walaupun output yang dihasilkan banyak, akan tetapi mutu dari hasil yang dihasilkan tidak baik dan tidak memenuhi standar perusahaan, maka kinerja perusahaan dapat dikatakan buruk. Oleh karena itu, kuantitas yang dihasilkan harus seiring dengan mutu dari hasil tersebut.

\section{Jangka waktu dari hasil}

Kemampuan dalam menghasilkan output harus cepat dan sesuai dengan waktu yang telah ditargetkan oleh perusahaan.

\section{Kehadiran di tempat kerja}

Kehadiran di tempat kerja berkaitan dengan disiplin dari karyawan untuk selalu hadir tepat waktu sesuai jam kerja dan dapat memberikan kontribusi positif bagi perusahaan.

\section{Sikap kooperatif}

Sikap kooperatif berupa suatu hubungan baik antara rekan sekerja dan hubungan yang baik antara atasan dan bawahan.

PT XYZ telah merancang suatu pedoman perilaku dalam perusahaan sebagai petunjuk dan etika dasar bagi semua karyawan dalam melaksanakan pekerjaan. Berdasarkan pedoman perilaku tersebut, semua karyawan diwajibkan untuk mengejar kinerjanya berdasarkan pedoman internal, mencegah konflik kepentingan dalam perusahaan, dan menghindari semua kegiatan yang bisa merugikan kepentingan perusahaan (Dahana, 2013).

Edrak et al. (2013) menyatakan bahwa tidak ada perbedaan gender dalam motivasi intrinsik dan ekstrinsik. Hal tersebut menunjukkan bahwa tidak ada perbedaan motivasi intrinsik dan ekstrinsik pada karyawan laki-laki dan perempuan. Penelitian lainnya yang dilakukan oleh Kappel (2012) dengan tiga kuesioner, yaitu: work preference inventory, job diagnostic survey dan brief demographics survey yang dianalisis dengan analisis regresi linier berganda, menemukan perbedaan dalam hubungan antara motivasi intrinsik dengan kepuasan kerja. Pada generasi milenium (Y) terdapat hubungan nyata dan positif motivasi intrinsik dengan kepuasan kerja sedangkan pada generasi baby boom terdapat hubungan yata dan negatif motivasi intrinsik dengan kepuasan kerja. Channar et al. (2011) melakukan penelitian dengan 526 orang yang terdiri dari pegawai negeri dan swasta laki-laki dan perempuan yang termasuk ke dalam kategori rendah, menengah dan tinggi bidang pendidikan dan kesehatan di Kabupaten Hyderabad dan Jamshoro. Pengujian hipotesis dilakukan dengan uji $t$, dimana di perusahaan swasta karyawan perempuan lebih mengalami diskriminasi dibandingkan dengan karyawan laki-laki. Dampak diskriminasi gender pada kepuasan dan motivasi, komitmen dan antusias, serta tingkat stress diukur menggunakan korelasi produk Pearson. Hasil pengukuran tersebut menunjukkan bahwa diskriminasi gender menurunkan kepuasan dan motivasi dan komitmen dan tingkat antusias karyawan dan menaikkan tingkat stress karyawan. Berdasarkan penjabaran tersebut, maka tujuan penelitian ini untuk menganalisis persepsi karyawan generasi $Y$ laki-laki dan perempuan pada kondisi kerja di PT $X Y Z$ serta menganalisis kinerja karyawan generasi Y laki-laki dan perempuan di PT XYZ.

\section{METODE PENELITIAN}

Penelitian dilaksanakan di PT XYZ, yang dipilih secara sengaja (purposive) berdasarkan pertimbangan bahwa PT XYZ merupakan industri strategik yang menyediakan layanan bahan peledak yang identik karyawannya didominasi oleh laki-laki, namun memberikan peluang kepada karyawan perempuan untuk berkarir dan memiliki program management trainee berada ke dalam kategori generasi $Y$. 
Teknik pengumpulan data dilakukan dengan kuesioner, wawancara dan studi dokumentasi. Kuesioner diberikan langsung kepada para responden (karyawan generasi $\mathrm{Y}$ laki-laki dan perempuan) untuk mendapatkan pernyataan yang diperlukan dalam penelitian ini. Wawancara terhadap informan (Staff PSDMO PT XYZ) untuk melengkapi hasil kuesioner. Studi dokumentasi menggunakan dokumen relevan untuk mendukung penelitian, yaitu laporan tahunan dan artikel-artikel mengenai PT XYZ.

Total jumlah karyawan yang termasuk ke dalam kategori generasi $\mathrm{Y}$ berjumlah 107 orang, terdiri dari 82 orang karyawan laki-laki dan 25 orang karyawan perempuan. Responden dipilih dengan metode pengambilan contoh acak (simple random sampling). Informan dalam penelitian ini adalah staff PSDMO. Rumus Slovin digunakan menentukan jumlah contoh dari populasi (Sumarwan et al, 2014). Rumus Slovin dalam penulisan matematika:

$$
\mathrm{n}=\mathrm{N} /\left(1+\mathrm{Ne}^{2}\right)
$$

Keterangan:

$\mathrm{N}$ : Jumlah populasi penelitian

$\mathrm{n}$ : Jumlah contoh penelitian

e : Batas galat, nilai kritis (batas ketelitian) yang diinginkan (persen kelonggaran ketidaktelitian karena kesalahan pengambilan contoh populasi)

Total karyawan generasi Y PT XYZ sebanyak 107 orang, terdiri dari 82 orang laki-laki dan 25 orang perempuan. Berdasarkan perhitungan dengan rumus Slovin, jumlah contoh yang diteliti 66 orang, meliputi 46 karyawan laki-laki dan 20 karyawan perempuan. Perhitungannya untuk karyawan laki-laki dan karyawan perempuan adalah: laki-laki:

Perhitungan contoh penelitian karyawan

$\mathrm{n}=82 /\left(1+82(0.1)^{2}\right)=82 /(1+0.82)$

$\mathrm{n}=45.05 \approx 46$ orang

Perhitungan contoh penelitian karyawan perempuan:

$\mathrm{n}=25 /\left(1+25(0.1)^{2}\right)=25 /(1+0.25)$

$\mathrm{n}=20$ orang

Tahap awal dari analisis data mendeskripsikan temuan dengan statistik deskriptif (Eriyanto, 2011). Statistik deskriptif bertujuan mendeskripsikan dan menjabarkan temuan dan data yang didapatkan dari analisis isi. Hasil analisis isi dapat dideskripsikan dalam bentuk tabulasi silang. Tabulasi silang adalah tabel dimana memasukkan dua atau lebih peubah. Peneliti menghubungkan dan menyajikan dua atau lebih peubah ke dalam satu tabel. Analisis rataan skor digunakan dalam menganalisis data secara deskriptif untuk mengetahui penilaian responden terhadap suatu pernyataan dalam kuesioner penelitian. Analisis rataan skor digunakan untuk mengetahui penilaian responden mengenai persepsi kondisi kerja dan penilaian PT $X Y Z$ mengenai kinerja karyawan generasi $Y$ yang menjadi responden. Tahap awal yang dilakukan dalam menganalisis secara deskriptif adalah mengelompokkan jawaban dan menentukan bobot sesuai urutan jawaban. Menurut Umar (2005), tahapan yang harus dilakukan dalam menentukan rentang kriteria adalah:

1. Mengelompokkan jawaban

Setiap responden memberikan jawaban atas pertanyaan-pertanyaan yang tertuang dalam kuesioner. Setiap pertanyaan yang diajukan memiliki tiga pilihan jawaban yang memiliki nilai bobot tertentu, yaitu:

Bobot 1 = Tidak

Bobot 2 = Ragu-ragu

Bobot $3=$ Ya

2. Menghitung skor

Semua jawaban yang telah dikelompokkan dihitung skornya pada setiap komponen dengan mengalikan jumlah frekuensi dari masing-masing indikator peubah dengan bobot sesuai rumus:

Skor $=\sum($ frekuensi jawaban $\mathrm{x}$ bobot skala $)$

3. Melakukan penilaian

Melakukan penilaian terhadap setiap indikator yang dinilai dalam kuesioner agar dapat ditarik kesimpulan mengenai tanggapan responden terhadap persepsi kondisi kerja dan kinerja karyawan generasi $\mathrm{Y}$.

Pengujian hipotesis dilakukan dengan uji Mann Whitney. Uji Mann Whitney digunakan untuk menguji perbedaan dua contoh bebas jika data yang digunakan berskala nominal (Suliyanto, 2014). Hipotesis nihil yang diuji adalah dua sampel independen diambil dari populasipopulasi yang mempunyai mean yang sama. Syarat $\mathrm{H}_{0}$ diterima atau tidak berdasarkan nilai probabilitas dengan $\alpha=0.1$ :

$\mathrm{H}_{0}$ diterima $\quad$ : jika peluang (Sig.) $>0.1$.

$\mathrm{H}_{0}$ ditolak $\quad$ : jika peluang (Sig.) $\leq 0.1$.

Hipotesis uji Mann Whitney untuk peubah persepsi kondisi kerja dan kinerja adalah: 
$\mathrm{H}_{0}$ : Tidak terdapat perbedaan persepsi kondisi kerja dan kinerja karyawan generasi $\mathrm{Y}$ berdasarkan jenis kelamin.

$\mathrm{H}_{1}$ : Terdapat perbedaan persepsi kondisi kerja dan kinerja karyawan generasi $Y$ berdasarkan jenis kelamin.

\section{HASIL DAN PEMBAHASAN}

\section{Karakteristik karyawan generasi $\mathbf{Y}$}

Responden dalam penelitian ini merupakan karyawan PT XYZ yang termasuk ke dalam generasi $\mathrm{Y}$ yang berusia 20-35 tahun yang telah lolos seleksi program management trainee. Responden penelitian berjumlah 66 orang, meliputi 46 orang karyawan laki-laki dan 20 orang karyawan perempuan. Responden yang terpilih diharapkan mampu mewakili kondisi populasi karyawan generasi $\mathrm{Y}$ yang ada di PT XYZ dalam memberikan tanggapan yang obyektif terhadap pertanyaan penelitian, agar dapat menggambarkan kondisi nyata lingkungan kerja dan dapat ditarik kesimpulan serta strategi yang tepat dalam menyelesaikan permasalahan yang ada.

Hasil penelitian menemukan bahwa responden karyawan generasi Y laki-laki lebih banyak dibandingkan dengan responden karyawan perempuan, yaitu contoh berjenis kelamin laki-laki (46 orang) dan contoh berjenis kelamin perempuan (20 orang). Meskipun PT XYZ memberikan peluang yang sama kepada perempuan untuk berkarir, namun jumlah karyawan laki-laki tetap lebih banyak dibandingkan dengan jumlah karyawan perempuan. Hal tersebut disebabkan oleh bisnis yang dijalankan oleh PT XYZ termasuk ke dalam industri berat yang pekerjaannya dominan dan identik dilakukan oleh laki-laki.
Oleh karena itu, populasi karyawan generasi $Y$ di PT XYZ lebih banyak berjenis kelamin laki-laki (82 orang) dibandingkan dengan perempuan (25 orang), sehingga peluang terpilihnya contoh karyawan laki-laki sebagai responden lebih besar dibandingkan dengan karyawan perempuan.

Generasi Y adalah generasi yang lahir antara tahun 1980-2000 (Meier dan Crocker, 2010). Sejalan hal tersebut, dalam penelitian ini, usia karyawan termasuk generasi $\mathrm{Y}$ berada pada rentang usia 20-35 tahun. Generasi Y merupakan generasi terbaru dari pekerja yang memasuki angkatan kerja saat ini. Tabel 2 menunjukkan karyawan generasi $\mathrm{Y}$ didominasi oleh rentang usia 25-30 tahun, yaitu 23 orang karyawan lakilaki $(50 \%)$ dan sembilan orang karyawan perempuan (45\%). Selanjutnya, diikuti oleh karyawan generasi $\mathrm{Y}$ pada rentang usia 30-35 tahun, yaitu 22 orang karyawan laki-laki $(47.8 \%)$ dan delapan orang karyawan perempuan (40\%). Sisanya, seorang karyawan laki-laki (2.2\%) dan tiga orang karyawan perempuan $(15 \%)$ berada pada rentang usia 20-25 tahun. Hasil penelitian tersebut menunjukkan bahwa pada karakteristik usia karyawan generasi Y, usia 25-30 tahun mendominasi dibandingkan dengan karyawan generasi $\mathrm{Y}$ yang berusia 20-25 tahun dan 30-35 tahun.

Berdasarkan karakteristik status pernikahan, jumlah karyawan generasi Y laki-laki yang sudah menikah lebih banyak dibandingkan dengan jumlah karyawan perempuan, (34 orang atau $73,9 \%$ ) karyawan laki-laki dan (6 orang atau $30 \%$ ) karyawan perempuan berstatus sudah menikah. Sisanya 12 orang karyawan laki-laki $(26,1 \%)$ dan 14 orang karyawan perempuan berstatus belum menikah (70\%).

Tabel 2. Sebaran jumlah dan persentase karyawan generasi Y berdasarkan karakteristik

\begin{tabular}{lllrrrr}
\hline \multirow{2}{*}{ No } & \multirow{2}{*}{ Karakteristik } & \multicolumn{2}{c}{ Karyawan Laki-Laki } & \multicolumn{2}{c}{ Karyawan Perempuan } \\
\cline { 3 - 6 } & & & Jumlah & Persentase & Jumlah & Persentase \\
\hline \multirow{2}{*}{ Usia } & $20-25$ tahun & 1 & 2,2 & 3 & 15 \\
& & $25-30$ tahun & 23 & 50,0 & 9 & 45 \\
& & $30-35$ tahun & 22 & 47,8 & 8 & 40 \\
\hline 2 & Status & Sudah menikah & 34 & 73,9 & 6 & 30 \\
& pernikahan & Belum menikah & 12 & 26,1 & 14 & 70 \\
\hline \multirow{2}{*}{3} & Tingkat & Diploma & 2 & 4,3 & 1 & 5 \\
& pendidikan & Sarjana & 42 & 91,3 & 13 & 65 \\
& & Pascasarjana & 2 & 4,3 & 6 & 30 \\
\hline \multirow{2}{*}{4} & Masa & $\leq 5$ tahun & 26 & 56,5 & 14 & 70 \\
& kerja & $>5-15$ & 20 & 43,5 & 6 & 30 \\
& & tahun & 46 & & 20 & \\
\hline
\end{tabular}


Zemke et al. dalam Kian dan Yussof (2012), menyadari bahwa karyawan generasi $\mathrm{Y}$ lebih kooperatif dan optimis dibandingkan dengan generasi sebelumnya, serta memiliki latar belakang pendidikan tinggi. Pernyataan tersebut sesuai dengan hasil penelitian ini, dimana tingkat pendidikan karyawan generasi Y laki-laki dan perempuan didominasi tingkat pendidikan sarjana (S1) (Tabel 2). Sebanyak 42 orang karyawan laki-laki $(91,3 \%)$ dan 13 orang karyawan perempuan (65\%) memiliki tingkat pendidikan sarjana. Karyawan laki-laki yang tingkat pendidikannya pascasarjana hanya dua orang $(4,3 \%)$ dan perempuan enam orang $(30 \%)$. Berdasarkan hal tersebut, diketahui persentase karyawan perempuan yang memiliki tingkat pendidikan pascasarjana lebih tinggi dibandingkan dengan persentase karyawan laki-laki. Hasil penelitian tersebut sesuai dengan pendapat Eisner dan Harvey (2009) yang menyatakan bahwa meskipun saat ini laki-laki dan perempuan yang bekerja memiliki tingkat pendidikan sama namun perempuan lebih banyak yang memperoleh gelar dibandingkan laki-laki.

Program management trainee sudah dilakukan sejak tahun 2002, ketika pertama kali PT XYZ melakukan transformasi. Saat ini, program management trainee sudah memiliki 13 angkatan. Berdasarkan hasil penelitian, jumlah karyawan generasi Y PT XYZ didominasi oleh karyawan yang sudah bekerja selama kurun waktu $\leq 5$ tahun, yaitu 26 orang karyawan laki-laki (56,5\%) dan 14 orang karyawan perempuan (70\%). Karyawan laki-laki dan perempuan yang sudah bekerja selama kurun waktu $>5-15$ tahun hanya 20 orang karyawan laki-laki $(43,5 \%)$ dan enam orang karyawan perempuan (30\%). Wentling (2003) dalam Wijayanti (2009) menyatakan bahwa salah satu faktor yang menghambat perkembangan karir perempuan adalah umur, dimana perempuan yang ingin mencapai posisi lebih tinggi seringkali terhalang dengan umur yang dianggap sudah tidak produktif. Selain itu, Eagly dalam Ghurobi (2014) menjelaskan bahwa perempuan memiliki risiko yang lebih besar dibandingkan laki-laki terkait dengan keterikatannya dalam keluarga, sebagai isteri dan sebagai ibu, sehingga memiliki usia karir yang lebih pendek.

Berdasarkan uraian di atas, karakteristik responden usia yang sudah matang dan tingkat pendidikan tinggi diharapkan mampu memberikan jawaban mengenai kondisi kerja dan kinerja yang dapat menggambarkan kondisi karyawan generasi Y di PT XYZ. Hasil jawaban tersebut digunakan sebagai sumber data dan informasi dalam perumusan strategi yang tepat untuk masalah yang sedang dihadapi oleh PT XYZ.

\section{Persepsi karyawan generasi $Y$ pada kondisi kerja di PT XYZ}

Persepsi mengenai kondisi kerja dan kinerja dalam penelitian ini diperoleh berdasarkan nilai rataan skor yang telah dijelaskan pada bab metodologi. Nilai rentang kriteria skala yang digunakan adalah 0,6. Angka 1 menunjukkan adanya persepsi negatif dan angka 3 menunjukkan adanya persepsi positif. Rentang kriteria yang digunakan untuk mengklasifikasikan penilaian variabel pada kategori jawaban responden dapat dilihat pada Tabel 3.

Tabel 3. Klasifikasi rentang kriteria

\begin{tabular}{ccc}
\hline Skor & Kategori & Rentang Kriteria \\
\hline 1 & Negatif & $1.0-1.6$ \\
2 & Netral & $1.7-2.3$ \\
3 & Positif & $2.4-3.0$ \\
\hline
\end{tabular}

\section{Persepsi karyawan generasi $Y$ pada kondisi kerja di PT XYZ}

Herzberg dalam Intani (2013) mengemukakan "Herzberg Two Factor Motivation Theory" yang menjelaskan dua jenis faktor yang mendorong seseorang untuk berusaha mencapai kepuasan dan menjauhkan diri dari ketidakpuasan. Dua faktor itu disebut dengan faktor ekstrinsik (faktor hygiene) dan faktor intrinsik (faktor motivator). Persepsi kondisi kerja dalam penelitian ini merupakan nilai rataan skor kondisi kerja intrinsik dan ekstrinsik. Kondisi kerja intrinsik terdiri dari prestasi, pengakuan, pekerjaan itu sendiri, tanggungjawab dan kemajuan, sedangkan kondisi kerja ekstrinsik terdiri dari kebijakan perusahaan, supervisi, hubungan interpersonal, kondisi kerja, gaji dan tunjangan. Nilai persepsi dari kedua faktor terkait kondisi kerja dimuat pada Tabel 4.

Persepsi kondisi kerja karyawan generasi $Y$ laki-laki dan perempuan memiliki nilai rataan skor 2,67 dan 2,49, termasuk ke dalam kategori positif. Kategori positif pada persepsi kondisi kerja menunjukkan bahwa karyawan generasi $Y$ laki-laki dan perempuan memiliki persepsi positif mengenai kondisi kerja yang ada di PT XYZ. Berdasarkan relasi gender, persepsi karyawan generasi Y laki-laki dan perempuan pada kondisi 
kerja di PT XYZ yang positif menunjukkan tidak terjadi manifestasi ketidakadilan gender dalam bentuk apapun di PT XYZ. Hal tersebut disebabkan oleh kentalnya suasana kekeluargaan yang dibangun oleh manajemen, sehingga tidak terjadi adanya diskriminasi, baik terhadap karyawan laki-laki maupun perempuan. Selain itu, budaya perusahaan yang diterapkan oleh PT XYZ mendukung dan memberikan perlakuan yang sama terhadap setiap individu PT XYZ untuk mampu mengembangkan proses dan atau jasa yang inovatif (proses dan output) didasari oleh pola pikir dan perilaku pembelajaran yang kreatif, dinamis, dan antisipatif.

Tabel 4. Nilai rataan skor persepsi karyawan generasi $\mathrm{Y}$ pada kondisi kerja di PT XYZ

\begin{tabular}{clcc}
\hline \multirow{2}{*}{ No } & Persepsi kondisi kerja & \multicolumn{2}{c}{ Jenis kelamin } \\
\cline { 3 - 4 } & & $\begin{array}{c}\text { Karyawan } \\
\text { laki-laki }\end{array}$ & $\begin{array}{c}\text { Karyawan } \\
\text { perempuan }\end{array}$ \\
\hline A & Faktor ekstrinsik & & \\
1 & Kebijakan perusahaan & 2,70 & 2,45 \\
2 & Supervisi & 2,85 & 2,73 \\
3 & Hubungan & 2,96 & 3,00 \\
& interpersonal & & \\
4 & Kondisi kerja & 2,80 & 2,62 \\
5 & Gaji dan tunjangan & 2,44 & 2,20 \\
\hline & Total faktor ekstrinsik & 2,75 & 2,60 \\
\hline B & Faktor intrinsik & & \\
6 & Prestasi & 2,64 & 2,38 \\
7 & Pengakuan & 2,30 & 2,05 \\
8 & Pekerjaan itu sendiri & 2,59 & 2,35 \\
9 & Tanggung jawab & 2,46 & 2,28 \\
10 & Kemajuan & 2,94 & 2,87 \\
\hline & Total faktor intrinsik & 2,59 & 2,39 \\
\hline & Total kondisi kerja & 2,67 & 2,49 \\
\hline
\end{tabular}

Tabel 4 menunjukkan persepsi karyawan generasi Y laki-laki dan perempuan pada kondisi kerja ekstrinsik yang lebih mengarah ke persepsi positif dibandingkan pada kondisi kerja intrinsik. Nilai rataan skor persepsi kondisi kerja ekstrinsik karyawan generasi Y laki-laki $(2,75)$ dan perempuan $(2,60)$. Nilai rataan skor persepsi kondisi kerja intrinsik karyawan generasi Y laki-laki $(2,59)$ dan perempuan $(2,39)$. Nilai rataan skor persepsi kondisi kerja ekstrinsik yang tinggi menunjukkan PT XYZ mampu membuat lingkungan kerja nyaman, sehingga dapat mendorong karyawannya untuk memberikan kinerja terbaiknya. Salah satu program yang dirancang oleh PT XYZ untuk menggali talenta karyawan dalam berbagai bidang seni dan menghibur karyawan di sela-sela kesibukannya bekerja, adalah program "tuesday move on" yang dilakukan sebulan sekali setiap hari Selasa pada minggu ketiga. Hasil penelitian ini diperkuat oleh hasil penelitian yang dilakukan Acar (2014), serta Hong dan Waheed (2011), bahwa bagi generasi $\mathrm{Y}$ motivasi ektrinsik merupakan faktor dominan dalam memotivasi dan lebih berpengaruh dibandingkan dengan motivasi intrinsik.

Nilai rataan skor yang mengarah positif pada persepsi indikator kondisi kerja ekstrinsik karyawan generasi Y laki-laki $(2,96)$ dan perempuan $(3,00)$ adalah hubungan interpersonal. Hubungan interpersonal yang terjalin di PT XYZ baik antara atasan, bawahan maupun sesama karyawan sangat kuat dan memotivasi karyawan generasi $\mathrm{Y}$ dalam bekerja. Karyawan merasa menjadi bagian dari keluarga besar PT XYZ. Hal tersebut senada dengan hasil penelitian yang dilakukan oleh Meier dan Crocker (2010), bahwa generasi $\mathrm{Y}$ mencari tantangan untuk mendapatkan pengetahuan dengan cara berdiskusi dan berinteraksi dengan karyawan lainnya dan bukan mencari perusahaan dimana akan bekerja setiap hari dari mulai pukul 08.00-17.00 tanpa berkomunikasi dengan karyawan lainnya. Oleh karena itu, banyak perusahaan yang membuat generasi $\mathrm{Y}$ nyaman dalam lingkungan kerjanya dengan cara memberikan fasilitas-fasilitas yang menyenangkan, seperti membuat kegiatan yang melibatkan seluruh karyawan, nonton film bersama di akhir pekan, olahraga bersama dan liburan. Hal tersebut dilakukan oleh PT XYZ, dimana dalam menyambut ulang tahunnya yang ke-50 melibatkan seluruh karyawannya untuk ikut serta menyukseskan kegiatan tersebut.

Nilai rataan skor netral menuju positif pada persepsi indikator kondisi kerja ekstrinsik karyawan generasi $Y$ perempuan (2.20) dan lakilaki (2.44) adalah gaji dan tunjangan. Nilai rataan skor menunjukkan adanya persepsi positif pada karyawan generasi $\mathrm{Y}$ laki-laki dan perempuan atas gaji dan tunjangan yang diterima. Karyawan generasi Y laki-laki dan perempuan belum merasa puas atas gaji dan tunjangan yang diterima. Padahal gaji merupakan salah satu unsur penting yang memiliki pengaruh besar dalam memotivasi karyawan. Meskipun PT XYZ tidak membedakan gaji dan tunjangan berdasarkan jenis kelamin. Hal tersebut disebabkan oleh kebijakan sistem kompensasi yang diberikan oleh PT XYZ berdasarkan $3 \mathrm{P}$, yaitu pay for position, pay for person, dan pay for performance. Berdasarkan hal tersebut, PT XYZ harus mengkaji ulang mengenai kebijakannya dalam penentuan jumlah gaji dan tunjangan, agar 
mampu memberikan rasa puas dan meningkatkan kinerja karyawannya.

Nilai rataan skor persepsi karyawan generasi Y laki-laki $(2,59)$ dan perempuan $(2,39)$ pada indikator kondisi kerja intrinsik, termasuk ke dalam kategori netral mengarah positif. Kondisi kerja intrinsik memiliki peranan dalam memotivasi karyawan. Nilai rataan skor persepsi kondisi kerja intrinsik yang lebih rendah menunjukkan motivasi yang ada dalam diri karyawan generasi Y laki-laki dan perempuan rendah. Oleh karena itu, untuk mendapatkan kinerja karyawan yang maksimal, PT XYZ harus mampu menyeimbangkan kondisi kerja intrinsik dan ekstrinsik karyawannya.

Nilai rataan skor persepsi indikator kondisi kerja intrinsik yang mengarah positif pada karyawan generasi $Y$ laki-laki $(2,94)$ dan perempuan $(2,87)$ adalah kemajuan. Nilai rataan skor indikator kemajuan yang tinggi menggambarkan bahwa PT XYZ sangat mendukung pengembangan potensi bagi karyawannya. memberikan kesempatan bagi seluruh karyawan untuk mengikuti pelatihan berjenjang termasuk pelatihan ke luar negeri bagi karyawan berprestasi dan mampu berkiprah di ajang internasional. Memberikan peluang promosi dan jenjang karir yang menjanjikan bagi seluruh karyawan. Memberikan apresiasi berupa wisata keliling kota selama tiga hari bersama keluarga. Wisata keliling kota bertujuan untuk meningkatkan prestasi dan membangun kepercayaan keluarga karyawan, sehingga keluarganya mendorong karyawan untuk meningkatkan kinerjanya.

Indikator persepsi kondisi kerja intrinsik yang memiliki nilai rataan skor terendah mengarah netral pada karyawan generasi $\mathrm{Y}$ lakilaki $(2,30)$ dan perempuan $(2,05)$ adalah pengakuan. Pengakuan atau penghargaan yang diberikan oleh atasan sangat berpengaruh dalam mendorong kinerja karyawan, karena karyawan merasa dihargai hasil kerjanya. Baah dan Amoako (2011) menjelaskan bahwa generasi $\mathrm{Y}$ membutuhkan kemajuan dan pengakuan dan kedua faktor ini sangat berpengaruh kuat dalam memotivasi untuk menghasilkan prestasi kerja baik. Senada dengan pernyataan Baah dan Amoako, Meier dan Crocker (2010) menyatakan bahwa pengakuan menurut generasi $\mathrm{Y}$ penting dan memotivasi untuk melakukan pekerjaan dengan baik. Kilber $e t$ al. (2014) mengemukakan bahwa meningkatkan pengakuan merupakan teknik terbaik yang dapat dilakukan manager untuk memotivasi karyawan generasi Y. Salah satu cara yang dapat dilakukan dengan mengirimkan sebuah kartu ucapan berisi pujian secara personal atas pekerjaan yang telah dilakukan dengan baik ke rumah karyawan generasi $\mathrm{Y}$.

\section{Kinerja karyawan generasi $\mathbf{Y}$}

Mathis dan Jackson (2002) mengatakan bahwa kinerja diartikan sebagai sesuatu hal baik yang dilakukan maupun yang tidak dilakukan. Kinerja karyawan sangat berpengaruh terhadap produktivitas perusahaan. Pengaruh ini dapat dilihat dari seberapa banyak kontribusi yang diberikan kepada perusahaan yang meliputi kuantitas dari hasil, mutu dari hasil, jangka waktu dari hasil, kehadiran di tempat kerja, dan sikap kooperatif (Tabel 5).

Tabel 5. Nilai rataan skor persepsi kinerja karyawan generasi $Y$

\begin{tabular}{llcc}
\hline \multirow{2}{*}{ No } & \multicolumn{1}{c}{ Kinerja } & \multicolumn{2}{c}{ Jenis kelamin } \\
\cline { 3 - 4 } & & $\begin{array}{c}\text { Karyawan } \\
\text { laki-Laki }\end{array}$ & $\begin{array}{c}\text { Karyawan } \\
\text { perempuan }\end{array}$ \\
\hline 1 & Kuantitas dari hasil & 2,83 & 2,65 \\
2 & Jangka waktu dari hasil & 2,91 & 2,83 \\
3 & Kualitas dari hasil & 2,96 & 2,73 \\
4 & Kehadiran di tempat kerja & 2,72 & 2,45 \\
5 & Kooperatif & 2,96 & 2,88 \\
\hline & Total Kinerja & 2,88 & 2,71 \\
\hline
\end{tabular}

Tabel 5 menunjukkan nilai rataan skor kinerja karyawan generasi Y laki-laki $(2,88)$ dan perempuan $(2,71)$ yang mengarah positif. Nilai rataan skor kinerja tinggi menyatakan bahwa karyawan generasi $\mathrm{Y}$ laki-laki dan perempuan sudah memberikan kinerja terbaiknya bagi PT XYZ. Hasil penelitian ini sesuai dengan pernyataan Saidl dalam Luntungan et al. (2014) bahwa generasi $\mathrm{Y}$ adalah generasi yang sangat mahal, namun di saat sama memiliki kinerja sangat tinggi (high maintenance yet high performance), yaitu sangat independen dan berharap bahwa kinerjanya dinilai dari hasil yang diberikan, bukan pada keberadaan rutinitas di kantor, karena menguasai teknologi dan menggunakan efektifitas proses.

Indikator sikap kooperatif merupakan suatu hubungan baik antara rekan kerja, serta hubungan baik atasan dan bawahan. Berdasarkan nilai rataan skor, indikator sikap kooperatif memiliki nilai tertinggi pada karyawan generasi $Y$ laki-laki $(2,96)$ dan perempuan $(2,88)$. Hal tersebut sejalan dengan penjabaran pada sub bab sebelumnya, bahwa pada persepsi kondisi kerja, indikator hubungan interpersonal memiliki nilai 
rataan skor tertinggi. Sikap kooperatif tinggi pada karyawan generasi Y mampu memberikan kinerja terbaiknya, sehingga dapat tercapai kinerja perusahaan. Selain indikator sikap kooperatif, indikator mutu dari hasil pada karyawan laki-laki memiliki nilai rataan skor sama $(2,96)$. Oleh karena itu, indikator sikap kooperatif dan mutu dari hasil memiliki nilai rataan skor tertinggi pada karyawan generasi Y laki-laki, sedangkan pada karyawan perempuan hanya indikator sikap kooperatif saja yang memiliki nilai rataan skor tertinggi.

Nilai rataan skor indikator kinerja yang terkecil pada karyawan generasi Y laki-laki $(2,72)$ dan perempuan $(2,45)$ adalah kehadiran. Kehadiran di tempat kerja berkaitan dengan disiplin dari karyawan untuk selalu hadir tepat waktu sesuai jam kerja dan dapat memberikan kontribusi positif bagi perusahaan. Meskipun nilai rataan skor indikator kehadiran terkecil berdasarkan klasifikasi rentang kriteria termasuk ke dalam kategori positif. Hal tersebut dapat disimpulkan, meskipun nilai rataan indikator kehadiran lebih rendah dibandingkan dengan nilai rataan skor indikator kinerja lainnya, maka kinerja karyawan generasi Y menurut kehadirannya termasuk kategori positif.

Uji beda persepsi kondisi kerja dan kinerja karyawan generasi $Y$

Uji beda Mann Whitney digunakan untuk melihat perbedaan respons dari dua populasi data yang saling independen, kondisi kerja dan kinerja karyawan generasi $\mathrm{Y}$ berdasarkan karakteristik jenis kelamin (Tabel 6). Hasil uji beda Mann Whitney pada indikator persepsi kondisi kerja dan kinerja karyawan generasi $\mathrm{Y}$ berdasarkan karakteristik jenis kelamin, menunjukkan peluang (Sig.) lebih kecil dari alpha $(0,1)$ pada indikator prestasi $(0,032)$, pekerjaan itu sendiri $(0,092)$, tanggungjawab $(0,009)$, kemajuan $(0,050)$ dan kondisi kerja (0.034). Probabilitas (Sig.) lebih besar dari alpha $(0,1)$ menyatakan bahwa $\mathrm{H}_{\mathrm{o}}$ ditolak. Artinya, terdapat perbedaan persepsi kondisi kerja karyawan generasi $\mathrm{Y}$ berdasarkan jenis kelamin laki-laki dan perempuan pada indikator prestasi, pekerjaan itu sendiri, tanggung jawab, kemajuan, dan kondisi kerja, serta dengan peluang (Sig.) lebih kecil dari alpha $(0,1)$ pada indikator jangka waktu dari hasil $(0,003)$, kehadiran di tempat kerja $(0,060)$ dan sikap kooperatif $(0,051)$. Dalam hal ini peluang (Sig.) lebih besar dari alpha $(0,1)$ menyatakan bahwa $\mathrm{H}_{\mathrm{o}}$ ditolak. Artinya, terdapat perbedaan kinerja karyawan generasi $\mathrm{Y}$ berdasarkan jenis kelamin laki-laki dan perempuan pada indikator jangka waktu dari hasil, kehadiran di tempat kerja, dan sikap kooperatif. Perbedaan ketiga indikator tersebut dipengaruhi oleh kompetensi yang dimiliki masing-masing karyawan untuk dapat menyelesaikan pekerjaannya dengan baik dan tepat waktu. Selain itu, adanya peningkatan hasil pekerjaan karyawan generasi $Y$ ke arah yang lebih baik dari waktu ke waktu. Kerjasama tim yang tercipta dengan baik antar sesama rekan kerja bertujuan untuk dapat memberikan kinerja terbaiknya agar target-target perusahaan dapat tercapai.

Tabel 6. Uji beda persepsi kondisi kerja dan kinerja karyawan generasi $\mathrm{Y}$ berdasarkan jenis kelamin (Sig.)

\begin{tabular}{lr}
\hline Peubah independen & Jenis kelamin \\
\hline Persepsi Kondisi Kerja & 0,032 \\
\hline Prestasi & 0,192 \\
Pengakuan & 0,092 \\
Pekerjaan itu sendiri & 0,009 \\
Tanggungjawab & 0,050 \\
Kemajuan & 0,170 \\
Kebijakan perusahaan & 0,269 \\
Supervisi & 0,128 \\
Hubungan interpersonal & 0,034 \\
Kondisi kerja & 0,154 \\
Gaji dan tunjangan & \\
\hline Kinerja Kerja & 0,235 \\
\hline Kuantitas dari hasil & 0,199 \\
Kualitas dari hasil & 0,003 \\
Jangka waktu dari hasil & 0,060 \\
Kehadiran di tempat kerja & 0,051 \\
\hline Sikap kooperatif & \\
\hline
\end{tabular}

\section{KESIMPULAN}

1. Persepsi kondisi kerja karyawan generasi $\mathrm{Y}$ laki-laki dan perempuan termasuk ke dalam kategori positif, dimana pada kondisi kerja ekstrinsik lebih mengarah ke persepsi positif dibandingkan pada kondisi kerja intrinsik. Persepsi kondisi kerja ekstrinsik karyawan generasi $\mathrm{Y}$ positif pada hubungan interpersonal, sedangkan persepsi kondisi kerja ekstrinsik netral menuju positif adalah gaji dan tunjangan. Persepsi kondisi kerja intrinsik karyawan generasi Y laki-laki dan perempuan termasuk ke dalam kategori positif pada kemajuan, serta persepsi kondisi kerja intrinsik karyawan generasi $Y$ netral pada pengakuan. 
2. Persepsi kinerja karyawan generasi Y laki-laki dan perempuan termasuk ke dalam kategori positif, dimana indikator sikap kooperatif memiliki nilai rataan skor tertinggi. Selain sikap kooperatif, nilai rataan skor kualitas dari hasil memiliki nilai rataan skor tertinggi pada karyawan laki-laki, serta indikator kehadiran memiliki nilai rataan skor terkecil ada karyawan perempuan dan laki-laki.

3. Hasil uji beda menunjukkan hasil bahwa:

a. Terdapat perbedaan persepsi kondisi kerja karyawan generasi $Y$ berdasarkan jenis kelamin laki-laki dan perempuan pada indikator prestasi, pekerjaan itu sendiri, tanggung jawab, kemajuan, dan kondisi kerja.

b. Terdapat perbedaan kinerja karyawan generasi Y berdasarkan jenis kelamin lakilaki dan perempuan pada indikator jangka waktu dari hasil, kehadiran di tempat kerja, dan sikap kooperatif.

\section{DAFTAR PUSTAKA}

Acar, A.B. 2014. Do Intrinsic and Extrinsic Motivation Factors Differ for Generation $X$ and Generation Y? International Journal of Business and Social Science, 5(5): 12-20.

Baah, K.D., G.K. Amoako. 2011. Application of Frederick Herzberg's Two-Factor Theory in Assessing and Understanding Employee Motivation at Work: A Ghanaian Perspective. European Journal of Business and Management, 3(9): 1-8.

Channar, ZA., Z. Abbassi, I.A. Ujan, 2011. Gender Discrimination in Workforce and Its Impact on The Employees. Pak. J. Commer. Soc. Sci, 5 (1): 177-191.

[Dahana] PT Dahana (Persero). 2013. Annual Report 2013: Green Economy for Sustainable Growth. Dahana, Subang.

Edrak, B.B., B.C. Yin Fah, B. Gharleghi, T.K. Seng. 2013. The Effectiveness of Intrinsic and Extrinsic Motivations: A Study of Malaysian Amway Company's Direct Sales Forces. International Journal of Business and Social Science, 4(9): 96-103.

Eisner, S.P. and M.E.O. Harvey. 2009. C Change? Generation $Y$ and The Glass Ceiling? SAM Advanced Management Journal, 74(1): 1328.

Eriyanto. 2011. Analisis Isi: Pengantar Metodologi untuk Penelitian Ilmu Komunikasi dan
Ilmu-Ilmu Sosial Lainnya. Kencana Prenada Media Group, Jakarta.

Ghurobi. 2014. Fenomena Glass Ceiling pada Sektor Publik. http://ghurobi0ne-fisip10. web.unair.ac.id/artikel_detail-92322-umumFenomena\%20Glass\%20Ceiling\%20pada\%2 0Sektor\%20Public.html (17 Februari 2016).

Hong, T.T., A. Waheed. 2011. Herzberg's Motivation-Hygiene Theory and Job Satisfaction in The Malaysian Retail Sector: The Mediating Effect of Love of Money. Asian Academy Of Management Journal, 16(1): 73-94.

Intani, L. 2013. Pengaruh Motivasi Kerja Terhadap Kinerja Pegawai Negeri Sipil di Kementerian Koordinator Bidang Politik Hukum dan Keamanan. Tugas Akhir [Tesis] Magister Manajemen, Sekolah Pascasarjana, Institut Pertanian Bogor.

Kappel, A.M. 2012. Generational Cohort as a Moderator Of The Relationship Between Extrinsic and Intrinsic Motivation and Job Satisfacion. Tugas Akhir [Disertasi]. Doctor of Philosophy, College of Social and Behavioral Sciences, Walden University.

Kian, T.S., W.F.W. Yussof. 2012. Generation X and $Y$ and Their Work Motivation. Proceeding Internal Conference of Technlogy Management, Business and Entrepreneurship 2012 (ICTMBEE 2012):396-408.

Kilber, J., A. Barclay, D. Ohmer. 2014. Seven Tips for Managing Generation Y. Journal of Management Policy and Practice, 15:(4). 8091.

Luntungan, I., A.V.S. Hubeis, E. Sunarti, A. Maulana. 2014. Strategi Pengelolaan "Generasi Y" di Industri Perbankan. Jurnal Manajemen Teknologi, 13(2):219-239.

Mangkuprawira, S., A.V.S. Hubeis,. 2007. Manajemen Mutu Sumber Daya Manusia. Ghalia Indonesia, Bogor.

Mathis, R.L., J.H. Jackson, 2002. Manajemen Sumber Daya Manusia. Salemba Empat, Jakarta.

Meier, J., M. Crocker. 2010. Generation Y in The Workforce: Managerial Challenges. The Journal of Human Resource and Adult Learning, 6(1): 68-78.

Rahayu, E.M. 2015. Empat Langkah Transformasi PT Dahana. Majalah SWA. http://swa.co.id/ business-strategy/management/empatlangkah-transformasi-pt-dahana\# (17 Februari 2016). 
Suliyanto. 2014. Statistika Non Parametrik Dalam Aplikasi Penelitian. Penerbit ANDI, Yogyakarta.

Sumarwan, U., A. Daryanto, N.A. Achsani, I. Fahmi, N.N. Suhendi, S. Palupi, L., F.D.V. Sijabat, A. Tobing, A. Kristiadi, A.T. Hardiyanto. 2014. Metode Riset Bisnis dan Konsumen. Sumarwan U, editor. IPB Pr, Bogor.
Umar, H. 2005. Metodelogi Penelitian: Aplikasi dalam Pemasaran. PT Gramedia, Jakarta.

Wijayanti. 2009. Glass Ceiling dalam Karir Wanita Mampukah Wanita Mengatasi Glass Ceiling? Jurnal Manajemen dan Bisnis, 2: 29-42. 